\title{
Periocular Histiocytoid Carcinoma: Potential Diagnostic Challenges
}

\author{
Joseph R. Yates ${ }^{a}$ Michael J. Mines ${ }^{c}$ Prem S. Subramanian ${ }^{d}$ \\ Roxana Rivera-Michlig ${ }^{b}$ Thomas J. Cummings ${ }^{\mathrm{e}}$ Charles G. Eberhart ${ }^{\mathrm{a}}{ }^{\mathrm{b}}$ \\ ${ }^{a}$ Department of Pathology, Johns Hopkins University School of Medicine, Baltimore, MD, USA; ${ }^{b}$ Department of \\ Ophthalmology, Johns Hopkins University School of Medicine, Baltimore, MD, USA; ' Ophthalmology Service, \\ Madigan Army Medical Center, Tacoma, WA, USA; dDepartment of Ophthalmology, University of Colorado School of

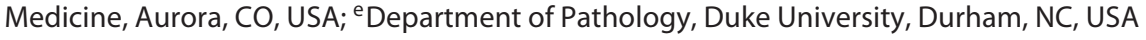

\section{Established Facts}

- Histiocytoid carcinomas can arise as primary lesions around the eye.

- Metastatic histiocytoid carcinoma can also involve the periocular region.

- No immunohistochemical or molecular markers that discriminate between these two possibilities are known.

\section{Novel Insights}

- GATA-3 can be expressed in primary periocular histiocytoid carcinoma.

- Histiocytoid carcinoma can occasionally show minimal cytological atypia and mimic nonneoplastic lesions.

\section{Keywords}

Histiocytoid carcinoma $\cdot$ Signet-ring cell carcinoma $\cdot$ Eyelid . Orbit - Metastasis

\section{Abstract \\ Cutaneous histiocytoid carcinoma can occur as a primary tumor of the periocular region. Morphologically similar his- tiocytoid carcinomas arising as primary tumors of the breast have a predilection for orbital metastases. They can occa-}

sionally contain regions with prominent vacuolated cytoplasm and minimal nuclear atypia, which mimic benign histiocytic lesions. Differentiating nonneoplastic, primary neoplastic, and metastatic histiocytoid lesions involving the periorbita can be challenging for both the clinician and the pathologist, and this distinction has management implications. Herein, we present 3 cases to illustrate the challenges of diagnosing periocular histiocytoid carcinoma.

(c) 2018 S. Karger AG, Basel

\section{KARGER}

(C) 2018 S. Karger AG, Basel

E-Mail karger@karger.com

www.karger.com/oop
Charles G. Eberhart, MD, PhD

Department of Pathology, Johns Hopkins University School of Medicine 720 Rutland Ave, Ross Building 558

Baltimore, MD 21205 (USA)

E-Mail ceberha@jhmi.edu 


\section{Introduction}

Periocular histiocytoid/signet-ring cell carcinomas are rare tumors. They can arise locally or metastasize from distant sites. Of the approximately 52 primary cutaneous histiocytoid/signet-ring cell carcinoma cases reported, 39 arose in the eyelid and/or orbit, whereas 13 arose in axillary skin [1-17]. These tumors are most common in elderly males $[2,12]$. Metastases have occurred in around half of the reported cases, usually to nearby lymph nodes $[2,12]$. Tumor-related deaths have also been described $[6,13,18$, 19]. The periorbital lesions often present as diffuse swelling and thickening of the involved lid, with normal or erythematous skin, and tend to infiltrate circumferentially around the eyelid, leading to their "monocle-like" appearance [20]. Clinical misdiagnosis is common, as benign inflammatory conditions, such as chalazion or chronic blepharoconjunctivitis have a similar presentation.

A histiocytoid variant of breast carcinoma has been documented but is also rare. Shimizu et al. [21] reviewed 1,010 primary breast cancer cases diagnosed between 1972 and 1996 and found only 6 with histiocytoid changes. One case of histiocytoid carcinoma in the male breast has been reported [22]. The tumors are most commonly regarded as a variant of lobular carcinoma, and their occasional occurrence with apocrine lobular carcinoma in situ and expression of GCDFP-15 suggest apocrine differentiation $[23,24]$. Both lobular and histiocytoid breast cancers can metastasize to the periocular region, often with bilateral involvement $[25,26]$. Hood and colleagues published the first series in 1973, which included 8 metastatic mammary carcinomas in the eyelid with a histiocytoid appearance. In several of these cases, the eyelid metastasis was identified before the primary tumor [27].

Unfortunately, primary and metastatic histiocytoid carcinomas can be morphologically and immunohistochemically indistinguishable from one another. Both are characterized by round to oval or polyhedral tumor cells with abundant histiocytoid cytoplasm showing variable vesicular or signet-ring features. Tumor cells generally diffusely percolate through the soft tissues in single-file formations or as individual cells, sometimes forming cohesive sheets, and express epithelial and apocrine markers. It can be a challenging diagnosis to make when only a few individual tumor cells are present in a biopsy. The histiocytoid cells can be misinterpreted as macrophages, especially when other inflammatory cells are present (Fig. 1). In this study, we present 3 cases of periocular histiocytoid carcinoma, which illustrate the challenges of differentiating primary and metastatic lesions.

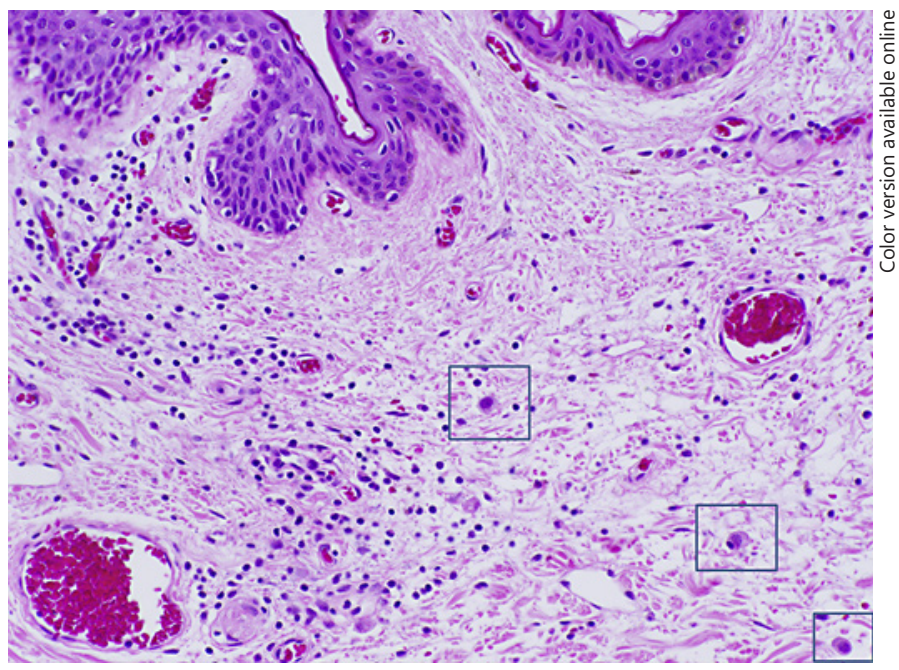

Fig. 1. A map biopsy of primary periocular histiocytoid carcinoma showing inflammation and only a few tumor cells in the biopsy (original magnification $\times 400$ ).

\section{Case Reports}

Case 1

A 68-year-old Caucasian male presented with a 2-year history of gradual decrease in vision and the sensation of a mass 'pushing' on his right eye. His past medical history was significant for noninsulin-dependent diabetes, hypertension, hypercholesteremia, and chronic obstructive pulmonary disease. On examination, he had limitation of extraocular motility and $4 \mathrm{~mm}$ of ptosis on the right side compared to the left. Magnetic resonance imaging (MRI) showed a $2.2 \times 4.9 \times 2.6 \mathrm{~cm}$ enhancing mass in the right superior, lateral, and anterior orbit extending along the superior and lateral aspect of the globe with ill-defined intraconal enhancement (Fig. 2). An extensive clinical workup, including whole-body positron emission tomography, failed to identify lesions outside the right periocular region.

An incisional biopsy of the right lower eyelid was taken and revealed a poorly differentiated adenocarcinoma. Orbital exenteration was subsequently performed. Microscopic examination revealed tumor cells involving the upper and lower eyelids, conjunctiva, lacrimal gland, extraocular muscles, and outer one-third of the sclera. No intraocular tumor was observed, and the optic nerve margin was negative. There were multifocal positive soft-tissue margins involving the superior, inferior, medial, and lateral orbit. The cells displayed a histiocytoid appearance with occasional signet-ring cells noted. The cells diffusely percolated through the dermis as solid collections, in single-file formations and as individual cells, sparing involvement of the epidermis. A mucicarmine stain highlighted signet-ring cells. Immunohistochemistry showed positivity for cytokeratin 7 (CK7), CAM 5.2, gross cystic disease fluid protein 15 (GCDFP-15), GATA-3, ER, PR, p63, carcinoembryonic antigen, EMA, and E-cadherin (Table 1). Immunohistochemical stains against CK20, CD68, CDX2, D2-40, S-100, HMB-45, Ber-EP4, mammaglobin, HER2/neu, thyroid transcription factor 1 (TTF-1), and prostate-specific antigen were negative. The Ki-67 
Fig. 2. Primary periocular histiocytoid carcinoma (Case 1). a Swelling of the right inferior eyelid. $\mathbf{b}$ MRI showing a mass in the right orbit. c Gross exenteration specimen of the right eye, with an extensive periocular mass involving the lower eyelid. d Single-file infiltration of neoplastic cells; signet-ring cells and mitosis can also be seen (original magnification $\times 400$ ). e GATA-3 expression in the tumor (original magnification $\times 400)$. $f$ ER expression in the tumor (original magnification $\times 200$ ).
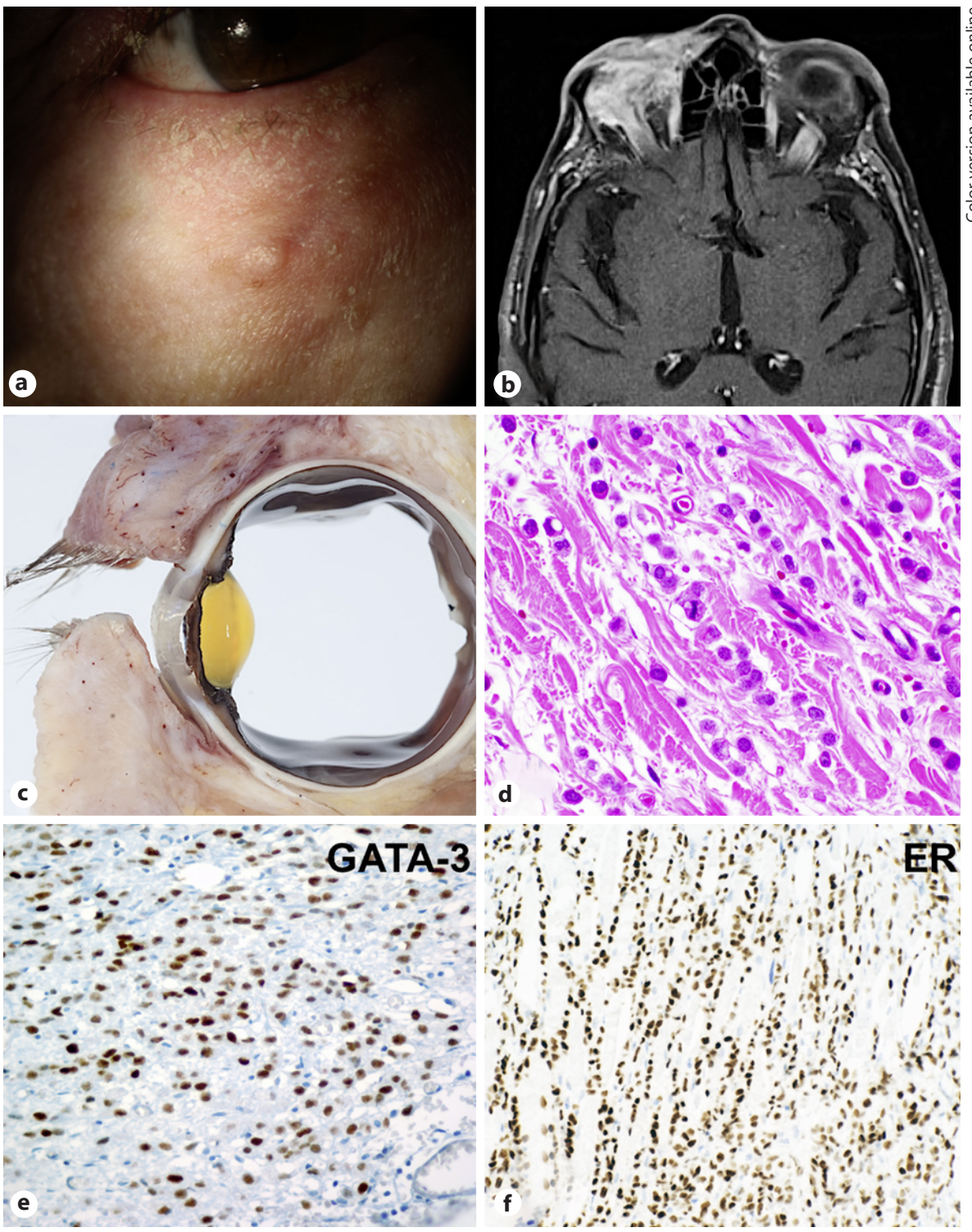

Table 1. Immunohistochemical data

\begin{tabular}{llllllllllllll}
\hline Case & CK7 & CK20 & CD68 & GCDFP-15 & GATA-3 & ER & PR & Her2neu & E-cadherin & p63 & D2-40 \\
\hline 1 & ++ & - & - & ++ & ++ & ++ & ++ & - & & ++ & + \\
2 & ++ & - & - & + & ++ & - & - & - & + & ++ & + & - & + \\
3 & ++ & - & - & ++ & ++ & - & - & - & & ++ & - & - & + \\
\hline
\end{tabular}

Negative (-); weakly positive (+); positive (++).

Yates/Mines/Subramanian/ Rivera-Michlig/Cummings/Eberhart 
Fig. 3. Metastatic histiocytoid breast carcinoma (Case 2). a Diffuse swelling of the periocular region. b Histiocytoid tumor cells with abundant vacuolated cytoplasm and limited nuclear pleomorphism (original magnification $\times 400)$. c Positive staining for CAM 5.2 (original magnification $\times 200$ ). d Weak staining for GCDFP-15 (original magnification $\times 400)$. e Positive staining for E-cadherin (original magnification $\times 400$ ). f Positive staining for GATA-3 (original magnification $\times 400$ ).
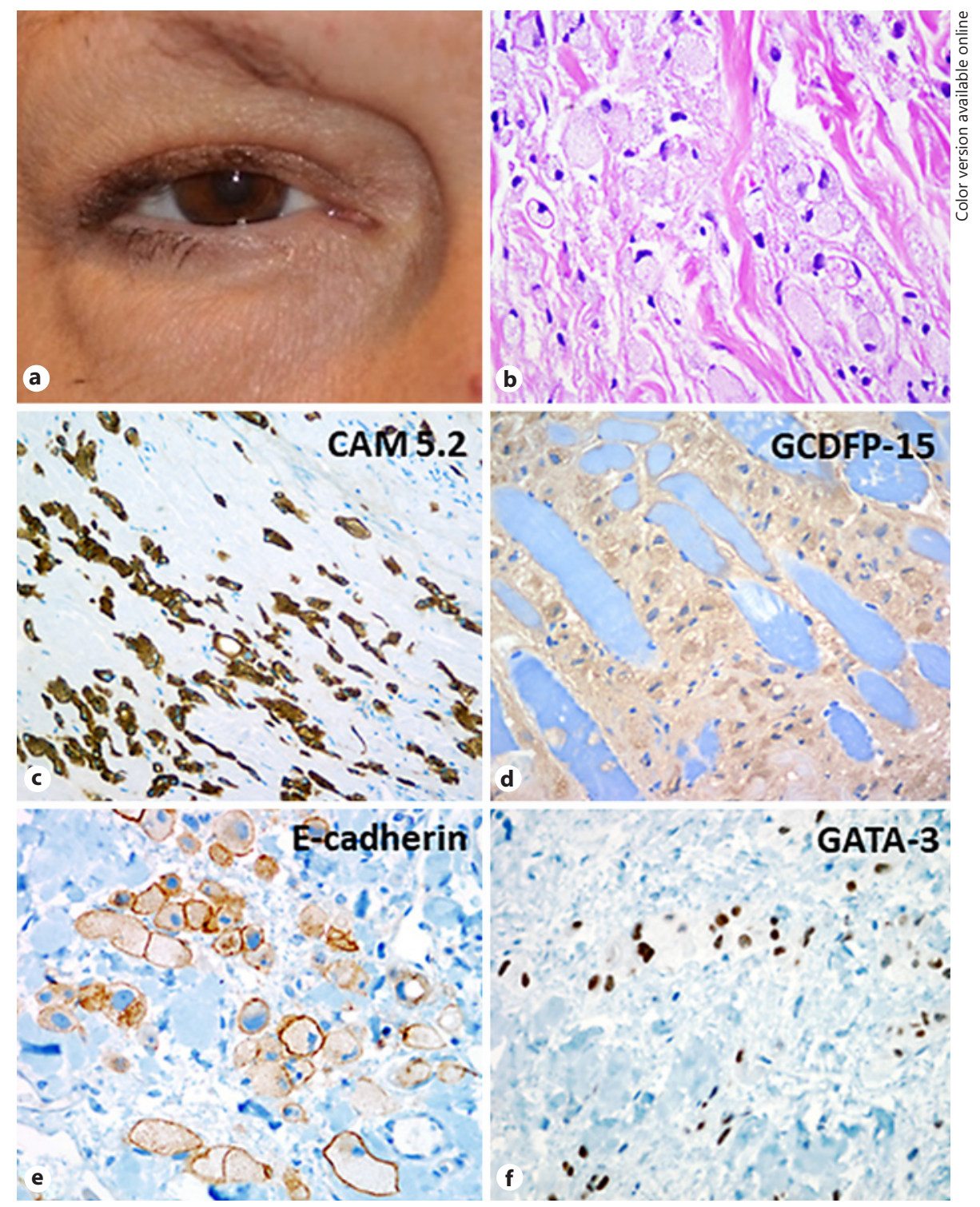

proliferation index was low. A diagnosis of primary periocular histiocytoid/signet-ring cell carcinoma was made. The patient declined adjuvant radiotherapy and passed away 20 months after diagnosis from chronic obstructive pulmonary disease and hypercalcemia.

\section{Case 2}

A 46-year-old female presented with a 4-month history of bilateral periorbital edema and firm nodules in both lower eyelids. The patient had experienced intermittent pain around both eyes during this period. She had a history of infiltrating histiocytoid lobular breast carcinoma and was treated by mastectomy 11 years before. Corresponding to the development of her lid nodules, she had a recurrence of her breast cancer and was found to have cervical lymph node metastases for which she received a 6-month regimen of Abraxane ${ }^{\circledR}$ chemotherapy. Clinical examination revealed firm masses involving the upper and lower lids bilaterally (Fig. 3). An ill-defined enhancement within the right orbit was seen on MRI, and the patient underwent an orbitotomy for biopsy.

Microscopically, the lesion consisted of round to oval cells with predominantly mild nuclear pleomorphism infiltrating in a single-file pattern and in small clusters through orbital muscle and fat. Most cells were notable for their pronounced histiocytic features, including abundant vacuolated cytoplasm, but were immunonegative for the macrophage marker CD68. The immunophenotype was strongly positive for CK7, CAM 5.2, cytokeratin AE1/AE3, GATA-3, and weakly positive for GCDFP-15, E-cadherin, and p63 (Table 1). ER stains were positive in the tumor cytoplasm but not in the nucleus. Immunostaining for CK20, PR, D2-40, TTF-1, and CDX2 were negative. HER2neu overexpression analysis was negative. The Ki67 proliferation index was 20$30 \%$. The histopathological and immunohistochemical findings 
Fig. 4. Histiocytoid carcinoma of unknown origin (Case 3). a CT scan showing right orbital preseptal soft-tissue thickening and enlargement of the lacrimal gland and medial rectus along with postsurgical changes after lateral orbitotomy. b H\&E-stained slide showing somewhat pleomorphic neoplastic cells scattered throughout (original magnification $\times 400$ ). c Positive staining for CK7 (original magnification $\times 400$ ). d Positive staining for GCDFP-15 (original magnification $\times 400)$. e Negative staining for CK20 (original magnification $\times 400$ ). f Negative staining for CD68 (original magnification $\times 400)$.
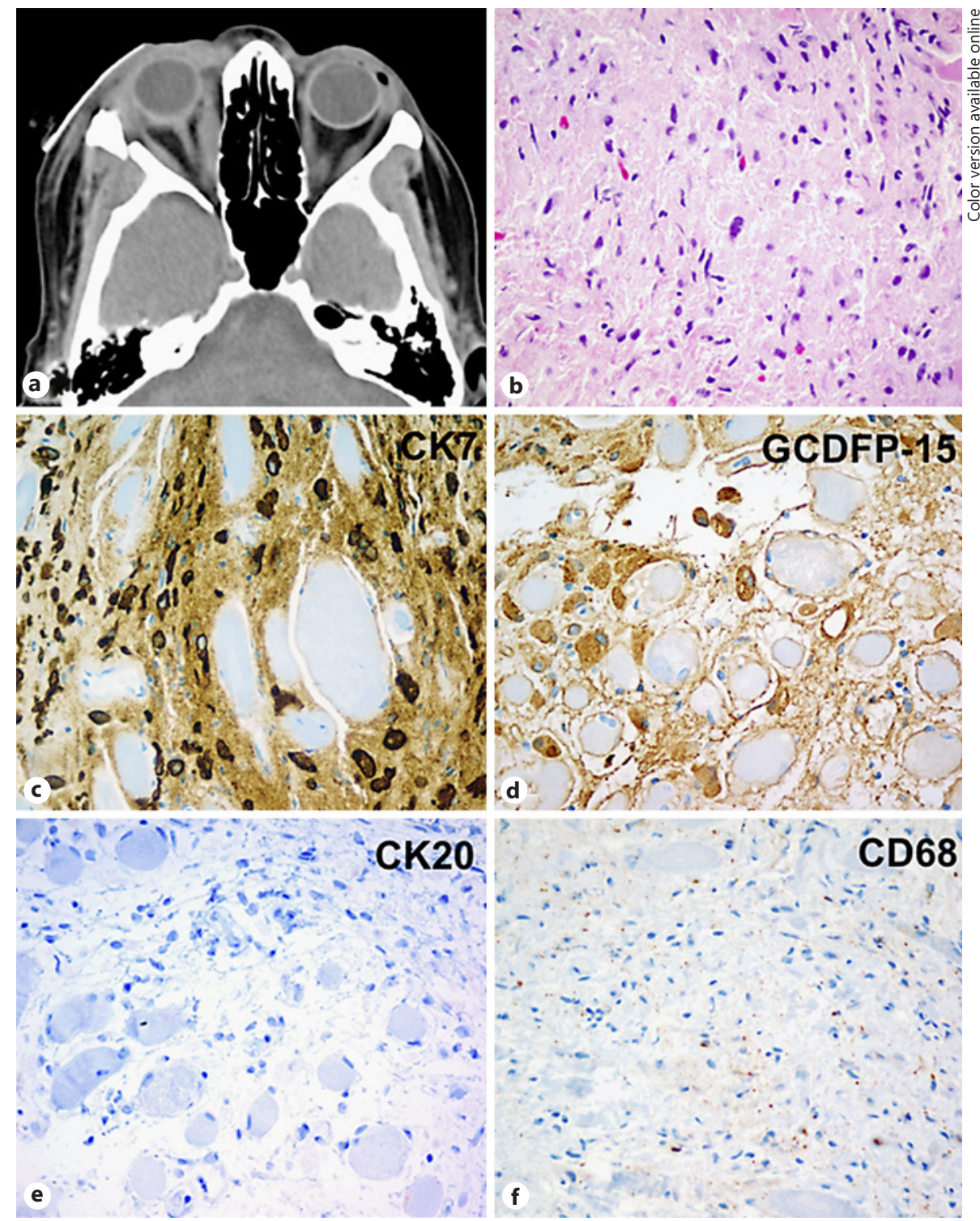

of the lesion were consistent with a diagnosis of orbital metastases of the histiocytoid variant of lobular breast cancer. The patient was lost to follow-up.

\section{Case 3}

An 83-year-old female presented with double and blurry vision. Her past medical history included in situ lobular carcinoma 35 years prior to presentation as well as invasive ductal carcinoma diagnosed 25 years ago and treated with lumpectomy and a radium implant. Her family history included breast carcinoma in her sister and daughter. Clinical examination revealed bilateral, asymmetrical limitation of upward gaze and $3 \mathrm{~mm}$ of right-sided proptosis. Computed tomography (CT) imaging demonstrated enlargement of the right superior, medial, and inferior recti muscles as well as the right lacrimal gland (Fig. 4). Contralaterally, the left lateral rectus muscle was enlarged. MRI also suggested in- volvement of the posterior sclera, optic nerve sheath, and lacrimal gland, and the patient was noted to have multiple punctate foci throughout the calvarium and the upper cervical vertebrae consistent with diffuse bony metastatic disease. These punctate foci were not seen on a previous MRI conducted 10 years before. Systemic evaluation was unrevealing including serologies and a CT/ positron emission tomography scan; there was no evidence of breast cancer recurrence.

Right lateral orbitotomy with an incisional muscle biopsy was performed. Microscopic examination revealed sheets of histiocytoid cells with abundant granular cytoplasm and bland nuclei infiltrating through the muscle and fat of the biopsies. The tumor cells were strongly positive for cytokeratin AE1/AE3 and CK7 and negative for CK20. The Ki67 proliferation index was moderate. GATA-3 and GCDFP-15 immunostains were both positive, while mammaglobin, ER, PR, and HER2neu immunostains were nega-
98

Ocul Oncol Pathol 2019;5:94-101

DOI: $10.1159 / 000490250$
Yates/Mines/Subramanian/ Rivera-Michlig/Cummings/Eberhart 
tive (Table 1). CD68, S100, TTF-1, CD1A, p63, and D2-40 immunostains were also negative. While the histology and immunohistochemistry (ER negative, PR positive) of her previous ductal carcinoma did not match that of the orbital lesion, the findings could be consistent with a diagnosis of infiltrating histiocytoid carcinoma of either primary or metastatic origin, including metastases from an undetected breast lesion. She received $40 \mathrm{~Gy}$ of palliative radiation split into 2 doses of 20 Gy delivered over a 2 -week period but refused chemotherapy. Over the next 3 years, she developed ascites, abdominal carcinomatosis, and passed away.

\section{Discussion}

These 3 cases document the similarities between primary histiocytoid carcinoma (Case 1), metastatic histiocytoid carcinoma (Case 2), and patients for whom this distinction is difficult (Case 3). Unfortunately, molecular and immunohistochemical markers that clearly differentiate primary and metastatic tumors are not known. In both, the neoplastic cells are immunopositive for cytokeratins CK7, AE1/AE3, CAM 5.2, and EMA, whereas they are generally immunonegative for CK20 [2, 24]. Positive immunoreactivity for GCDFP-15, carcinoembryonic antigen, and Ber-EP4 has also been reported [2, 24]. E-cadherin is immunopositive in around $80 \%$ of the primary periocular histiocytoid carcinoma cases, whereas immunoreactivity is seen in only $25 \%$ of the histiocytoid breast carcinomas cases $[1-5,20,22,28-34]$. Among the 17 cases of primary periocular histiocytoid carcinoma, which assessed ER and PR, there was immunoreactivity in 35 and 33\%, respectively [1-6, 20,35-42]. HER2neu overexpression was negative in all 6 reported cases $[1,3$, 5,39 ]. In comparison, immunoreactivity for $E R, P R$, and HER2neu in 29 cases of histiocytoid breast carcinoma was 44,19 , and $57 \%$, respectively $[21,22,26,29,31-34$, 43-46].

GATA-3, a transcription factor involved in maintaining luminal epithelial differentiation in the adult mammary gland, represents a possible marker for discriminating primary from metastatic disease not previously assessed in primary periocular histiocytoid carcinoma [47, 48]. Miettinen et al. [49] observed GATA-3 expression in $92 \%$ of the primary ductal carcinomas $(n=179)$, in $96 \%$ of the metastatic ductal carcinomas $(n=51)$, and in $100 \%$ of the primary lobular carcinomas $(n=38)$. However, there was positive immunoreactivity to GATA-3 in all our cases, including the primary tumor. Other skin adnexal tumors are known to express GATA-3; thus, this is not completely unexpected $[49,50]$. The marker may have diagnostic utility if metastatic gastrointestinal signet-ring cell carcinoma is on the differential diagnosis, as this neoplasm should be negative.

The histogenesis of primary cutaneous histiocytoid/ signet-ring cell carcinoma is still debated. In earlier reports, the neoplasm was thought to originate from eccrine sweat glands. Rosen et al. [51] and Thomas et al. [19] conducted ultrastructural studies and found both clear and dark cells and intracytoplasmic lumina with villi, which favored an eccrine origin. More recent reports have favored apocrine differentiation because the tumor has Periodic Acid-Schiff-positive diastase-resistant secretions and positive immunostaining for the apocrine marker GCDFP-15 [1]. In addition, Jakobiec et al. [52] observed abundant smooth and rough endoplasmic reticulum, granular cytoplasmic inclusions, cytoplasmic lumina, and lipid droplets at the ultrastructural level, which is suggestive of an apocrine origin. However, the neoplasm lacks morphological apocrine secretion, and GCDFP-15 immunoreactivity has been reported in normal eccrine glands $[38,53,54]$. From a theoretical viewpoint, it is possible that these tumors can arise from either eccrine or apocrine glands. Further research is therefore needed before definitive conclusions can be drawn.

With regards to Case 3, a diagnosis of recurrent metastatic breast carcinoma was favored given the family history, bilateral involvement, pathological findings, and evidence of extensive bony metastases seen on imaging. However, it should be noted that imaging and clinical examination failed to reveal a primary breast lesion. Prolonged follow-up was recommended as the primary breast lesion may become apparent in the future. Interestingly, her previous invasive ductal carcinoma was ER negative and PR positive, whereas the periocular lesion was ER and PR negative. It is possible for the metastatic profile of the tumor to be different from the primary process, so this would not rule out recurrence. An invasive focus in her prior lobular carcinoma in situ could also have been missed. Finally, the periocular lesion may represent a new occult histiocytoid breast carcinoma. This would explain the differences in histopathology between the original primary ductal carcinoma and the suspected periocular metastasis. Primary periocular histiocytoid carcinoma should also remain on the differential diagnosis, as a primary origin for the suspected metastatic lesion was not found.

While both primary and metastatic histiocytoid carcinomas of the eyelid and orbit are uncommon, other histiocytic lesions are not [55]. Noncancerous granuloma- 
tous lesions composed of histiocytes, potentially similar in appearance to histiocytoid carcinoma cells, can be seen in various processes including xanthelasma. Case 2 highlights how some regions of these carcinomas can mimic nonneoplastic histiocytes and show rather minimal atypia. Cytokeratin or CD68 immunohistochemical staining is a useful discriminator if diagnostic doubt exists.

\section{Statement of Ethics}

The study complied with the guidelines for human studies and was approved by the institute's committee on human research.

\section{Disclosure Statement}

The authors have no conflicts of interest to declare.

\section{References}

1 Requena L, Prieto VG, Requena C, Sarasa JL, Manzano R, Seco M, et al: Primary signet-ring cell/histiocytoid carcinoma of the eyelid: a clinicopathologic study of 5 cases and review of the literature. Am J Surg Pathol 2011;35: 378-391.

2 Tanboon J, Uiprasertkul M, Luemsamran P: Signet-ring cell/histiocytoid carcinoma of the eyelid: a case report and review of the literature. Am J Dermatopathol 2013;35:e1-e5.

3 Bernardez C, Macias Del Toro E, Ramirez Bellver JL, Martinez Menchon T, Martinez Barba E, Molina-Ruiz AM, et al: Primary signet-ring cell/histiocytoid carcinoma of the eyelid: a "binocle" presentation of the "monocle tumor." Am J Dermatopathol 2016;38: 623-627.

4 Hansen MS, Chi SL, Cummings T, Woodward JA: Uncorrectable ptosis: primary cutaneous signet-ring cell carcinoma. Dermatol Online J 2013;19:19615.

5 Iwaya M, Uehara T, Yoshizawa A, Kobayashi $\mathrm{Y}$, Momose M, Honda T, et al: A case of primary signet-ring cell/histiocytoid carcinoma of the eyelid: immunohistochemical comparison with the normal sweat gland and review of the literature. Am J Dermatopathol 2012; 34:e139-e145.

6 Sakamoto K, Ito T, Tanioka F, Fukamizu H, Tokura Y: Primary signet-ring cell/histiocytoid carcinoma of the eyelid expressing androgen receptors and treated with bicalutamide. J Dermatol 2017;44:e230-e231.

7 Seredyka-Burduk M, Burduk PK, Bodnar M, Malukiewicz G, Kopczynski A: Bilateral primary histiocytoid eccrine sweat gland carcinoma of eyelids. Braz J Otorhinolaryngol 2016, Epub ahead of print.

8 Tan JS, McKelvie PA, Hardy TG: Primary signet ring cell carcinoma of the eyelid. Orbit 2013;32:399-401.

9 Nazareth MR, Bogner P, Mansour N, Raghu PR, Mansour TN, Zeitouni NC: Primary adenocarcinoma of the eyelid with signet ring cell and histiocytoid features. Dermatol Surg 2012;38:1882-1885.

10 Pryds A, Venzo A, Heegaard S, Prause JU, Toft PB: Sentinel node biopsy and frozen section procedure in signet ring cell carcinoma of the eyelid and orbit. Acta Ophthalmol 2014;92:486-487.
11 Droubi D, Zeitouni NC, Skitzki J, Bogner PN: Primary signet-ring cell carcinoma of the axilla. J Cutan Pathol 2013;40:269-273.

12 Ishida M, Okabe H: Primary signet-ring cell/ histiocytoid carcinoma of the axilla. Pathol Int 2013;63:374-376.

13 Berdugo J, Dumont-Mackay V, Brissy-Lachery S, Leclerc YE, Doyon J, Mitchell A, et al: Cutaneous apocrine carcinoma with an in situ component and histiocytoid and signet-ring cells. Am J Dermatopathol 2017;39:e76-e78.

14 Misago N, Shinoda Y, Okawa T, Aoki S, Toda S, Koike K, et al: Histiocytoid and signet-ring cell carcinoma of the axilla: a type of cutaneous apocrine carcinoma equivalent to histiocytoid lobular carcinoma of the breast? Clin Exp Dermatol 2011;36:874-877.

15 Miyake T, Yamasaki O, Sugiu M, Hamada T, Otsuka M, Yanai H, et al: Primary signet-ring cell/histiocytoid carcinoma of the axilla expressing human epidermal growth factor receptor 2. J Dermatol 2012;39:1038-1040.

16 Philips R, Langston L, Hwang H, Vandergriff T, Trynosky T, Berlingeri-Ramos AC: Primary cutaneous histiocytoid carcinoma with distant metastasis. J Cutan Pathol 2017;44:376380.

17 Pai RR, Kini JR, Achar C, Rau A, Kini H: Apocrine (cutaneous) sweat gland carcinoma of axilla with signet ring cells: a diagnostic dilemma on fine-needle aspiration cytology. Diagn Cytopathol 2008;36:739-741.

18 Bellman B, Gregory NA, Silvers D, Fountain KS: Sweat gland carcinoma with metastases to the skin: response to 5-fluorouracil chemotherapy. Cutis 1995;55:221-224.

19 Thomas JW, Fu YS, Levine MR: Primary mucinous sweat gland carcinoma of the eyelid simulating metastatic carcinoma. Am J Ophthalmol 1979;87:29-33.

20 Mortensen AL, Heegaard S, Clemmensen O, Prause JU: Signet ring cell carcinoma of the eyelid - the monocle tumour. APMIS 2008; 116:326-332.

21 Shimizu S, Kitamura H, Ito T, Nakamura T, Fujisawa J, Matsukawa H: Histiocytoid breast carcinoma: histological, immunohistochemical, ultrastructural, cytological and clinicopathological studies. Pathol Int 1998;48:549556.
22 Hutchinson CB, Geradts J: Histiocytoid carcinoma of the male breast. Ann Diagn Pathol 2011;15:190-193.

23 Walford N, ten Velden J: Histiocytoid breast carcinoma: an apocrine variant of lobular carcinoma. Histopathology 1989;14:515-522.

24 Tan PH, Harada O, Thike AA, Tse GM: Histiocytoid breast carcinoma: an enigmatic lobular entity. J Clin Pathol 2011;64:654659 .

25 Tomasini C, Soro E, Pippione M: Eyelid swelling: think of metastasis of histiocytoid breast carcinoma. Dermatology 2002;205:63-66.

26 Jakobiec FA, Stagner AM, Homer N, Yoon MK: Periocular breast carcinoma metastases: predominant origin from the lobular variant. Ophthal Plast Reconstr Surg 2017;33:361366.

27 Hood CI, Font RL, Zimmerman LE: Metastatic mammary carcinoma in the eyelid with histiocytoid appearance. Cancer 1973;31:793800.

28 Warrick JI, Lewis JS Jr, Diaz JA: Pathology quiz case 2. Primary signet ring carcinoma of the eyelid. Arch Otolaryngol Head Neck Surg 2010;136:1146, 8-9.

29 Fujiwara M, Horiguchi M, Mori S, Yokoyama K, Horiguchi H, Fukazawa M, et al: Histiocytoid breast carcinoma: solid variant of invasive lobular carcinoma with decreased expression of both E-cadherin and CD44 epithelial variant. Pathol Int 2005;55:353-359.

30 Gupta D, Croitoru CM, Ayala AG, Sahin AA, Middleton LP: E-cadherin immunohistochemical analysis of histiocytoid carcinoma of the breast. Ann Diagn Pathol 2002;6:141147.

31 Li P, Zheng J, Zhang T, Cao R, Chen X, Geng M: Histiocytoid breast carcinoma: a case report showing immunohistochemical profiles. Int J Clin Exp Pathol 2013;6:2609-2614.

32 Murali R, Salisbury E, Pathmanathan N: Histiocytoid change in breast carcinoma: a report of 3 cases with an unusual cytomorphologic pattern of apocrine change. Acta Cytol 2006; 50:548-552.

33 Omeroglu G, Holloway CM, Spayne J, Nofech-Mozes S: Histiocytoid variant of lobular carcinoma: a triple negative case. Breast J 2010;16:84-86 
34 Reis-Filho JS, Fulford LG, Freeman A, Lakhani SR: Pathologic quiz case: a 93-yearold woman with an enlarged and tender left breast. Histiocytoid variant of lobular breast carcinoma. Arch Pathol Lab Med 2003;127: 1626-1628.

35 Kramer TR, Grossniklaus HE, McLean IW, Orcutt J, Green WR, Iliff NT, et al: Histiocytoid variant of eccrine sweat gland carcinoma of the eyelid and orbit: report of five cases. Ophthalmology 2002;109:553-559.

36 Wollensak G, Witschel H, Bohm N: Signet ring cell carcinoma of the eccrine sweat glands in the eyelid. Ophthalmology 1996;103:17881793.

37 Auw-Haedrich C, Boehm N, Weissenberger C: Signet ring carcinoma of the eccrine sweat gland in the eyelid, treated by radiotherapy alone. Br J Ophthalmol 2001;85:112-113.

38 Gonzalez-Lois C, Rodriguez-Peralto JL, Serrano-Pardo R, Martinez-Gonzalez MA, Lopez-Rios F: Cutaneous signet ring cell carcinoma: a report of a case and review of the literature. Am J Dermatopathol 2001;23:325328.

39 Langel DJ, Yeatts RP, White WL: Primary signet ring cell carcinoma of the eyelid: report of a case demonstrating further analogy to lobular carcinoma of the breast with a literature review. Am J Dermatopathol 2001;23:444449.

40 Fb FB, Hofman V, Lagier J, Gastaud P, Santini J, Hofman P: Primary signet ring cell carcinoma of the eccrine sweat gland in the eyelid. Immunohistochemical and ultrastructural study of a case (in French). J Fr Ophtalmol 2002;25:547-551.
41 Swinson B, Ryan F, Barrett AW, Jerjes W, Landon G, Calonje E, et al: Histiocytoid eccrine sweat gland carcinoma of the eyelid: report of a case. Clin Exp Dermatol 2006;31: 786-789.

42 Khoramnia R, Mayer C, Glaser E, Weirich G: Primary signet ring cell carcinoma of the eyelid in a young woman. Eye (Lond) 2011;25: 1380-1382.

43 Ciobanu M, Eremia IA, Pirici D, Craitoiu S: Breast invasive lobular carcinoma: a retrospective clinicopathologic study of 25 cases. Rom J Morphol Embryol 2012;53:533-548.

44 Kasashima S, Kawashima A, Zen Y, Ozaki S, Kobayashi M, Tsujibata A, et al: Expression of aberrant mucins in lobular carcinoma with histiocytoid feature of the breast. Virchows Arch 2007;450:397-403.

45 Yu J, Dabbs DJ, Shuai Y, Niemeier LA, Bhargava R: Classical-type invasive lobular carcinoma with HER2 overexpression: clinical, histologic, and hormone receptor characteristics. Am J Clin Pathol 2011;136:88-97.

46 Rongioletti F: Monocle and mask-like metastasis: two cases of eyelid metastasis from breast carcinoma - role of isotopic phenomenon? Int J Dermatol 2015;54:e136-e139.

47 Asselin-Labat ML, Sutherland KD, Barker H, Thomas R, Shackleton M, Forrest NC, et al: Gata-3 is an essential regulator of mammarygland morphogenesis and luminal-cell differentiation. Nat Cell Biol 2007;9:201-209.
48 Kouros-Mehr H, Slorach EM, Sternlicht MD, Werb Z: GATA-3 maintains the differentiation of the luminal cell fate in the mammary gland. Cell 2006;127:1041-1055.

49 Miettinen M, McCue PA, Sarlomo-Rikala M, Rys J, Czapiewski P, Wazny K, et al: GATA3: a multispecific but potentially useful marker in surgical pathology: a systematic analysis of 2500 epithelial and nonepithelial tumors. Am J Surg Pathol 2014;38:13-22.

50 Mertens RB, de Peralta-Venturina MN, Balzer BL, Frishberg DP: GATA3 Expression in normal skin and in benign and malignant epidermal and cutaneous adnexal neoplasms. Am J Dermatopathol 2015;37:885-891.

51 Rosen Y, Kim B, Yermakov VA: Eccrine sweat gland tumor of clear cell origin involving the eyelids. Cancer 1975;36:1034-1041.

52 Jakobiec FA, Austin P, Iwamoto T, Trokel SL, Marquardt MD, Harrison W: Primary infiltrating signet ring carcinoma of the eyelids. Ophthalmology 1983;90:291-299.

53 Saga K: Histochemical and immunohistochemical markers for human eccrine and apocrine sweat glands: an aid for histopathologic differentiation of sweat gland tumors. J Investig Dermatol Symp Proc 2001;6:49-53.

54 Mazoujian G, Margolis R: Immunohistochemistry of gross cystic disease fluid protein (GCDFP-15) in 65 benign sweat gland tumors of the skin. Am J Dermatopathol 1988;10:2835.

55 Gordon LK: Orbital inflammatory disease: a diagnostic and therapeutic challenge. Eye (Lond) 2006;20:1196-1206. 